\title{
Using data from large scale farming operations to understand the importance of feeding the ewe to improve whole farm performance
}

\author{
D.R. STEVENS ${ }^{1}$ and G. YOUNG ${ }^{2}$ \\ ${ }^{1}$ AgResearch Invermay, Private Bag 50034, Mosgiel \\ ${ }^{2}$ Landcorp Farming Ltd, PO Box 5349, Wellington 6145
}

David.Stevens@agresearch.co.nz

\begin{abstract}
The collection and use of data from large scale farming operations provided significant insights into drivers of sheep performance. These drivers included minimum two-tooth liveweight at tupping, ewe condition and pasture cover at lambing and the importance of weaning weight on whole farm performance. Using this data to demonstrate the influence of management decisions resulted in an increase in average lamb liveweight gain between birth and weaning of approximately $20 \mathrm{~g}$ /day in Landcorp Farming Ltd East Coast flocks over the 4 years of monitoring. Lambing percentage was harder to change, though individual farms increased lambing percentage by up to $35 \%$ by concentrating on increasing feed allocation and maintaining ewe body condition score during winter. Low liveweight in some two-tooth ewes was inversely related to the percentage of dries in a flock and prompted more emphasis on growing replacement stock. The programme shifted focus from short-term tactical feeding and management decisions to long-term strategies such as stock and sales policies that placed the breeding flock as the major priority.
\end{abstract}

Keywords: breeding ewes, data, lambing percentage, lambs, liveweight gain, whole flock analysis.

\section{Introduction}

Landcorp Farming has 74 sheep and beef farms throughout New Zealand running 575600 sheep and 88900 beef cattle at 30 June 2012. Depending on location, climate and land type, they are used for breeding, growing and/or finishing sheep and beef cattle to market specifications. Most farms carry a mix of sheep and cattle (and some also have deer). Typically, flock and herd progeny are bred and finished on the same farms. However there are still significant numbers of animals transferred at weaning from breeding to finishing units. Finishing uses the monitoring of animal growth against specific weight criteria to determine when they are sent for meat processing. Average lamb carcass weight was $17.9 \mathrm{~kg}$ and total sheep meat production was $10176 \mathrm{t}$ in 2011/12.

All animals are predominantly pasture fed on perennial ryegrass and clover species. Other legumes, brassicas and fodder crops are grown as a part of pasture renewal programmes and to meet supplementary winter feed requirements. The geographical spread of properties enables Landcorp to integrate their management during periods of drought, with livestock transferred between farms to mitigate losses in production.

Sheep flocks are predominantly Romney ewes in the North Island and Landcorp's Landmark composite in the South Island. Where heavyweight lean lamb production is the specific goal, terminal sires are usually either Texel or Landcorp's Lamb Supreme composite breed. Landcorp's annual lambing rate is consistently higher than the New Zealand industry average, being $139 \%$ in 2011/12 compared with a national average of approximately $125 \%$ (Beef + Lamb NZ 2013). Lambs are sent to processors mainly between December and April, for supply to both export and local meat markets.

Landcorp Farming Ltd has run a high performance sheep programme in both the North and South Island since August 2009. The aim is to enable the improvement of sheep performance as a key part of continued excellence and leadership in farming. Aims have been to improve lamb growth rate and lamb survival. This paper documents how on-farm data have been used to highlight areas for improvement and inform farm management decisions to enable change and improve on farm productivity.

\section{Methods}

Two farms were chosen in August 2009 as a focus for the Landcorp high performance sheep programme. These were Hindon on the Otago Plateau in the South Island and Parikanapa on hill country just south of Gisborne in the North Island. These farms have provided a focus for improvement and problem solving for their regions and provided stimulus for change on other farms using aspects of both discussion group and monitor farm approaches. The initial productivity goal for the Otago/Southland group of 18 farms, farming approximately 160000 breeding ewes, was to improve lamb survival. The North Island East Coast group of 13 farms, farming approximately 120000 breeding ewes, focused on growth rates of the lamb, particularly from birth to weaning. 


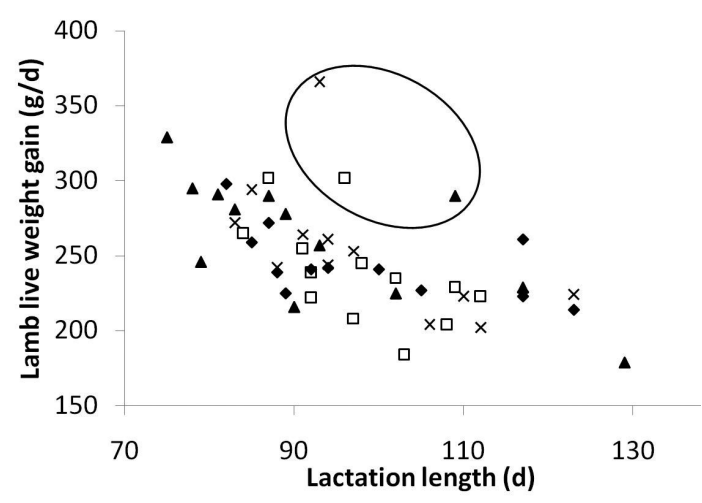

Figure 1 Lamb live weight gain from birth to weaning on North Island East Coast sheep farms in 2009/10

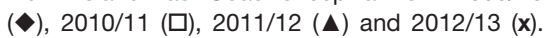
Some outliers are indicated within the ellipse.

The programme included two field days each year where sheep performance of the farm and other regional farms was documented and discussed. The groups included the farm managers, farm staff, business managers and a scientist. The focus of the groups was to identify what data to collect and how to use it to make changes. Each of the farms within the group reported on their experience of managements that had been tried to improve flock performance. Problems were highlighted and solutions identified. The power of the group was then available to other members as they aimed to implement changes to improve their own performance.

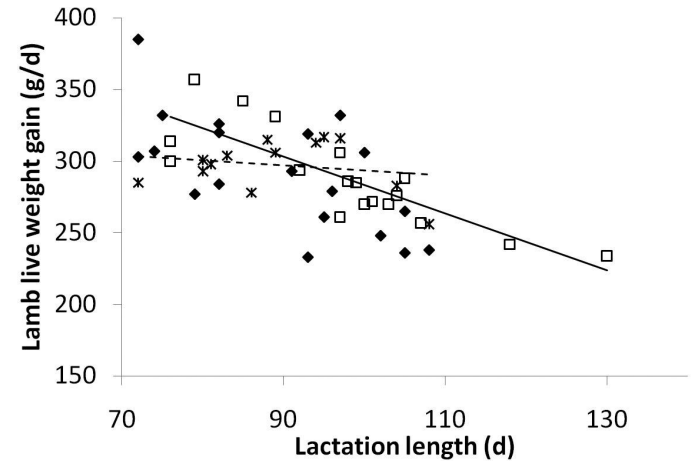

Figure 2 Trends in lamb liveweight gain from birth to weaning in Otago/Southland flocks in 2006/7 ( ), 2009/10 ( $\square$ ) and 2011/12 (x), with a general trend of declining lamb live weight gain with increasing lactation length (solid line). No relationship between lactation length and lamb live weight gain is present in 2011/12 (dotted line).

A key tenet for the groups was that the data collected must improve decision-making, otherwise it shouldn't be collected. The general approach was to examine data from both the Focus Farm and the wider group to define trends that could be used. Of specific interest were average daily lamb liveweight gain from birth to weaning and reproductive parameters of scanning and lambing percentage. Case studies of high performance or changing performance were used to illustrate biological principles and opportunities to improve management decision making.

Table 1 The reproductive performance of Landcorp Farming Ltd farms on the East Coast (13 farms) and in Otago/Southland (18 farms).

\begin{tabular}{|c|c|c|c|c|c|}
\hline & & & Year & & \\
\hline & Stock Class & Region & 2010 & 2011 & 2012 \\
\hline \multicolumn{6}{|c|}{ Number of dry ewes (\% of ewes mated) } \\
\hline & \multirow[t]{2}{*}{ 2-Tooth } & East Coast & 5.7 & 6.9 & 5.9 \\
\hline & & Otago/Southland & 3.0 & 4.6 & 3.4 \\
\hline & \multirow[t]{2}{*}{ Mixed age ewes } & East Coast & 2.8 & 3.6 & 4.1 \\
\hline & & Otago/Southland & 2.1 & 3.0 & 3.7 \\
\hline \multicolumn{6}{|c|}{ Lambs present at pregnancy scanning (\% of ewes mated) } \\
\hline & \multirow[t]{2}{*}{ 2-Tooth } & East Coast & 159 & 153 & 167 \\
\hline & & Otago/Southland & 170 & 173 & 185 \\
\hline & \multirow[t]{2}{*}{ Mixed age ewes } & East Coast & 171 & 167 & 172 \\
\hline & & Otago/Southland & 182 & 184 & 192 \\
\hline \multicolumn{6}{|c|}{ Lambs present at weaning ( $\%$ of ewes mated) } \\
\hline & \multirow[t]{2}{*}{ 2-Tooth } & East Coast & 121 & 130 & 132 \\
\hline & & Otago/Southland & 125 & 130 & 127 \\
\hline & \multirow[t]{2}{*}{ Mixed age ewes } & East Coast & 132 & 139 & 147 \\
\hline & & Otago/Southland & 133 & 143 & 132 \\
\hline \multirow[t]{2}{*}{ Number of breeding ewes } & & East Coast & 121,600 & 119,600 & 124,700 \\
\hline & & Otago/Southland & 160,200 & 156,900 & 159,900 \\
\hline
\end{tabular}




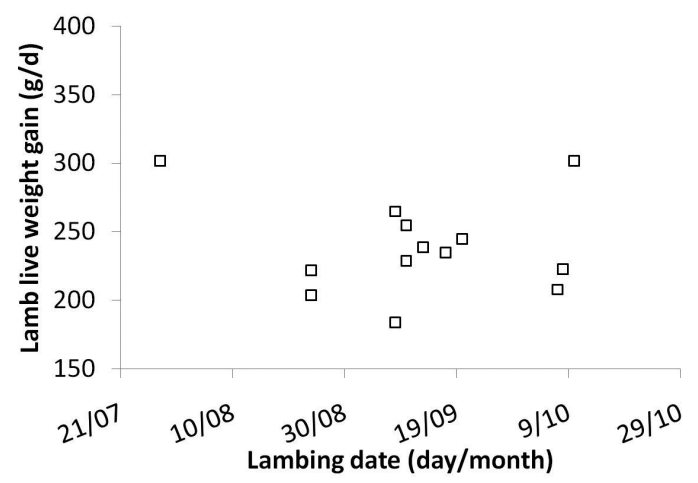

Figure 3 An examination of the relationship between lambing date and the live weight gain of lambs from birth to weaning in East Coast North Island farms in 2010.

\section{Results}

Lamb weaning weights and the potential causes of the variation that occurred were examined. A negative relationship was found between average daily lamb liveweight gain and lactation length (days between mean lambing date and weaning) for both the East Coast (Figure 1) and Otago/Southland data (Figure 2). Outliers to the major trend are indicated within the ellipse on Figure 1. Within the Otago/Southland data this decline in lamb growth in late spring has been subsequently reduced in the Otago/Southland group in 2011 (Figure 2). Lambing date had no significant effect on lamb growth rate on East Coast farms (Figure 3).

The East Coast group increased average lamb liveweight gain by approximately $20 \mathrm{~g} /$ day over the four years. This translates into an increase in 100 day weaning weight of $2 \mathrm{~kg} / \mathrm{lamb}$. Maximum recorded lamb liveweight gain also increased over this time, but the minimum recorded lamb liveweight gain remained unchanged (Figure 4).

Examination of the pregnancy scanning data indicated that there was an increase in scanning percentage of approximately $2 \%$ for every $\mathrm{kg}$ increase in liveweight at mating (Figure 5). The Otago/ Southland flocks were heavier and accordingly had higher scanning percentages than the East Coast flocks. The reproductive performance of hoggets (Figure 5) was more variable and did not conform to the general liveweight relationship.

Further examination of the data identified a significant occurrence of dry ewes within the East Coast flocks (Figure 6). This was not well related to the average liveweight of the ewes (Figure 6a). However, a negative trend was found between dry ewe percentage and minimum ewe liveweight (Figure 6b) with an increase in the percentage of dry ewes accelerating when the minimum ewe weight was below $54 \mathrm{~kg}$,

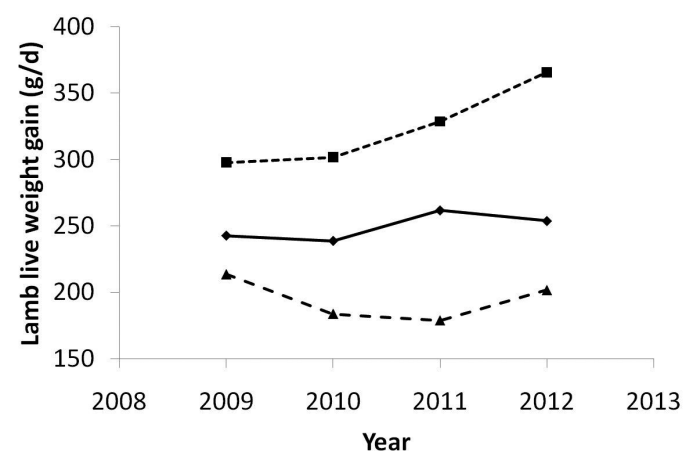

Figure 4 Lamb liveweight gain from birth to weaning in East Coast North Island flocks ( $\Delta$ minimum, $\bullet$ average and maximum).

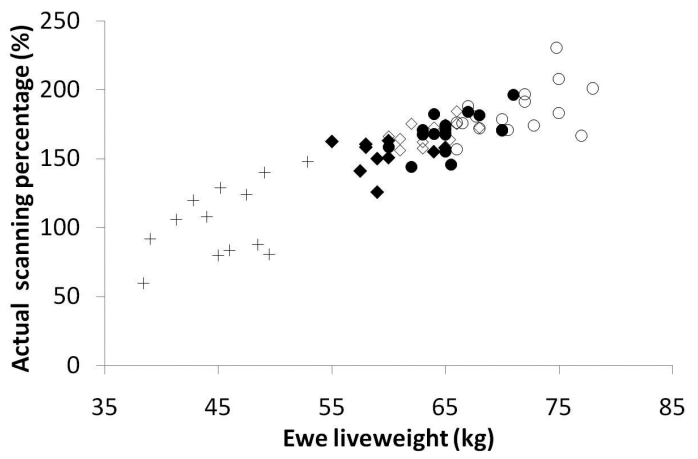

Figure 5 The pregnancy scanning percentages of flocks on the East Coast $(-2$ tooths; - mixed age ewes) and Otago/Southland $(\diamond$ 2-tooths; $\bigcirc$ mixed age ewes; + hoggets) in 2009.

especially in two tooth ewes.

Overall lambing percentage has made some progress, but is more variable in the South Island (Table 1) even though pregnancy scanning is greater in the South Island flocks.

\section{Discussion}

While other factors such as internal parasites, facial eczema, zearalenone etc. may have a role in altering performance, the underlying principles of ewe liveweight, minimum two-tooth liveweight, ewe body condition score, especially pre-lambing, and pasture cover at lambing were identified as the key drivers of the farming systems. The performance of individual farms was able to be used to demonstrate the importance of these drivers.

The interpretation of these graphs suggested that there was potential to increase the average daily lamb growth rate from birth to weaning at both the beginning of the spring and later in spring. The key factors restricting lamb growth during lactation were 


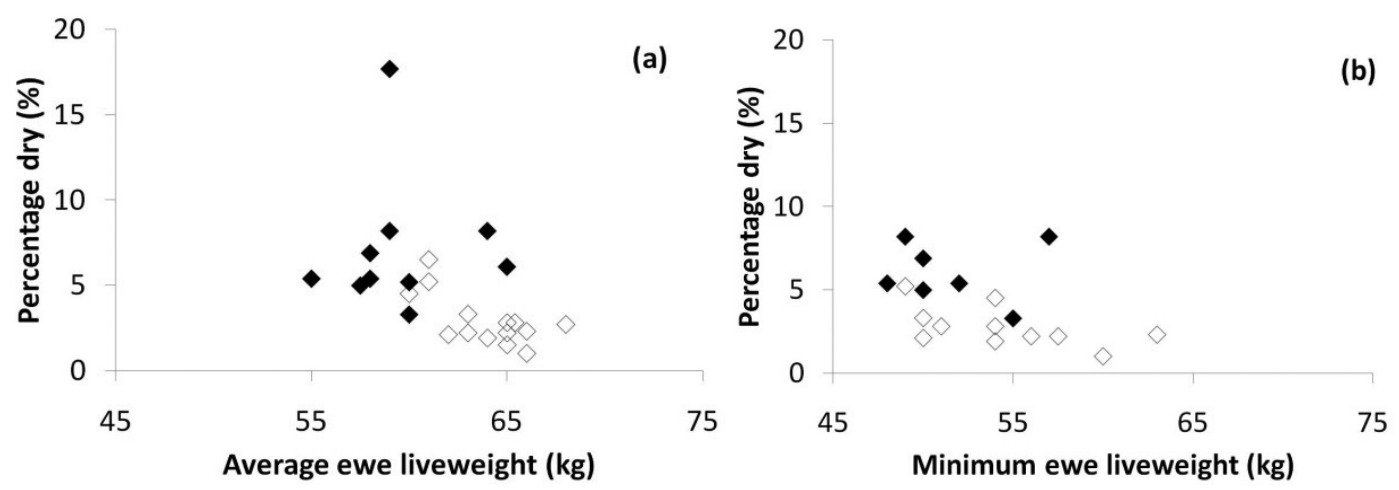

Figure 6 An analysis of ewes in the East Coast flocks to help determine the effects of live weight on the percentage of dries present.

identified as low feed supply or poor ewe condition in early spring, and feed quality in late spring. Litherland et al. (2002) documented the decline in late spring pasture quality, however close examination of the data suggests that the decline in pasture quality is similar in both Otago/Southland and the East Coast of the North Island during November and December. Analysis of the Otago/Southland farm data in 2011/12 demonstrated that lamb growth rate no longer declined as weaning date was extended suggesting that there are late spring management decisions that can rectify the problem as farmers implement management strategies specific to their farms. The farms were spread over a range of altitudes and topography with a range in lambing dates from August to October to fit the spring feed supply. Some of the changes that were made were to change lambing date.

Within both the East Coast and Otago/Southland data sets were outliers, both high and low, that confirmed the significant role of management in realising the potential growth rates from birth to weaning. Some farms were finishing farms on high quality land and these provided consistently higher daily liveweight gains of lambs from birth to weaning. However, the management practices associated with these farms were used to demonstrate the principles to achieve the goals of high lamb growth during lactation. Data such as pasture cover at lambing and ewe liveweight and body condition score were used in diagnosis. While the Otago/Southland average daily lamb growth rate from birth to weaning was approximately $50 \mathrm{~g} /$ day higher than the East Coast results, this may be due to whole farm systems fit rather than declining feed quality. East Coast farms have traditionally had relatively early lambing dates due to the propensity for regular summer dry periods, compared with Otago/Southland. This may mean that a potential mismatch of feed supply and demand occurs which is masking the potential to improve pre-weaning lamb growth.
In one example a property of 2140 ha, running 10000 ewes and 1000 breeding cows in low fertility (Olsen P 9, pH 5.3) Gisborne hill country increased pre-weaning average daily liveweight gain of lambs from $226 \mathrm{~g} /$ day to $302 \mathrm{~g}$ /day from 2009 to 2010 , while days to weaning decreased from 117 to 87 at the same time, with lamb liveweight at weaning remaining at approximately $30 \mathrm{~kg}$. The inability to feed ewes in winter and have good covers going into spring began with the limited availability of high quality summer feed. A lack of high quality summer feed led to low post-weaning lamb growth rate and late transfer of forward store lambs (30 kg liveweight). This reduced feed cover in early winter and so impacted on early spring feed supply, regardless of nitrogen fertiliser use. The chosen solutions concentrated on ensuring that the ewe flock was at body condition score 3 at lambing and that pasture supply was adequate at lambing to increase weaning weight and reduce the demand for high quality feed in summer. This required several changes. The first was to delay lambing date by 10 days to 25 September, while having 1 -year ewes mated 10 days before this to a terminal sire (14\% of the flock). These ewes and lambs were then sold in December providing a buffer against dry summers. Foetal aging was used to identify ewes lambing in 10 day bands to allow fine tuning of prelambing feed budgets. Body condition scoring was used to identify ewes that were below a condition score of 3 for preferential feeding throughout the year. Pasture cover targets were adjusted throughout the year and included both lower and upper limits (Spring 1300 $2000 \mathrm{~kg} \mathrm{DM} / \mathrm{ha}$ ) to ensure that both feed quantity and quality targets were met. All cattle were rotationally grazed throughout the year to help achieve those targets for the sheep flock. When feed budgeting, a utilisation factor of $80 \%$ was applied to all requirements to ensure that intake targets were met. These changes increased average daily lamb liveweight gain during lactation, increased weaning weight and decreased the time that 
forward store lambs were held on the property. This then increased the available feed in autumn, removed the need for regular nitrogen fertiliser use in spring and also resulted in an increase in lambing percentage from $135 \%$ to $150 \%$ in subsequent years.

The process of change and improvement takes time as illustrated by Cocks et al. (2002) with average increases in lamb liveweight gain from birth to weaning of $20 \mathrm{~g}$ /day over 4 years. As farms implemented new systems the results were not always positive. Often farms aiming to increase early spring supply ran into problems of feed quality in late spring.

Variations from the general trend of increasing scanning percentage with liveweight gain were investigated and solutions suggested. These included genetics, as some farms were not using Landcorp genetics and generally performed below average. Other solutions included abortion vaccination programmes, nutrition to achieve target mating weights during summer instead of using autumn feed for flushing and targeting lighter ewes for preferential feeding within each mob.

Progress in lamb survival has been significantly slower than gains in pre-weaning average daily lamb liveweight gain. Lamb losses in Otago/Southland were significantly greater than in the East Coast group. On some farms this may be a reflection of the occurrence of severe weather events with significant snow storms affecting both groups during the monitoring period. However, examination of the data suggests that some farms continue to achieve a consistent result regardless of the climatic conditions. A key management factor is the use of feed allocations that are well above the New Zealand industry standards. Current industry recommendations (Beef + Lamb NZ 1994) suggest that a $65 \mathrm{~kg}$ ewe bearing twins has a feed requirement rising from 14.5 MJME/day 6 weeks before lambing to 22.5 MJME/day at lambing. These feed requirements have been replaced by the use of a feed calculator based on AFRC (1993) recommendations and including a 15\% adjustment for "trampling" losses. This then increases the feed allocation to $17 \mathrm{MJME} /$ day 6 weeks before lambing rising to $28 \mathrm{MJME} /$ day at lambing. Body condition score monitoring has confirmed that these allocations are required to maintain condition score. With this approach one farm has increased lambing percentage from $130 \%$ to $165 \%$ in the Otago/Southland group.

The variable occurrence of dry ewes within North Island flocks (Figure 6) was investigated further and was found to be better related to the lightest sheep in the flock, rather than the average. This generated a change in the recording and use of ewe liveweight data with greater emphasis on variability. It also highlighted that two-tooth ewe liveweights may be holding back the performance of the flocks overall, and so shifted some of the focus from trying to get the most out of the mixed age ewe to growing the ewe hogget better to create a more consistent result overall.

As the programme has developed the group focus has shifted away from short term tactical decisions towards long term whole farm solutions. The focus has moved from relatively short term solutions such as "should I keep condition on my ewes in late winter or make sure my lambing cover is high enough" towards a bigger picture view of the importance of the breeding flock and its replacements throughout the year. Improved matching of feed supply to those true requirements have resulted in an increase in the performance of lambs and finishing stock.

Improving the performance of the flock by growing out ewe lambs and hoggets to become high performing two-tooth ewes provides significant benefits. Hogget lambing becomes an option and is now used on three East Coast farms and six Otago/Southland farms. The mature size of the ewe flock will increase, but information from the Otago/Southland group and within the East Coast group show that farm performance will also increase, as lambing percentage increases and ewes are better able to provide a consistent lamb weaning weight. Another opportunity that will become more wide spread as lambing percentage increases is greater use of terminal sires, which adds to lamb growth rate and weaning weight. Lower ewe losses will also lead toward a lower replacement rate and more lambs for sale.

\section{Conclusions}

The Landcorp Farming Ltd high performance sheep group has used its own data to help demonstrate the potential of the properties and highlighted potential solutions. The collection of agreed data across a wide range of farm systems means that the data is relatively robust when comparing farms both within and between the groups. The solutions that are developed start with specific aims and discussion of the underlying principles of feed supply and demand that will influence the outcomes of ewe condition, lamb survival and lamb weaning weight. Managers of each farm then investigate how they might implement those solutions with the resources available. This process includes discussion about labour, fit with other farm enterprises and operations, infrastructure, and potential benefits. Often the solutions are implemented within the constraints of current feed supply.

Interpreting on-farm data for whole farm change goes well beyond simple cause and effect and needs significant understanding of the biological processes 
before solutions are found. The examination of the data from both North and South Island properties and a comparison of their performance have provided the opportunity to demonstrate that basic biological principles of productivity apply universally. Lessons from these data sets can be applied to the whole of the sheep farming industry to aid improved profitability on-farm.

\section{ACKNOWLEDGEMENTS}

Many thanks to all of the Landcorp Farming Ltd farm managers and staff who have provided the data and contributed to the many discussions and interpretations of the managements that have been implemented.

\section{REFERENCES}

AFRC 1993. Energy and protein requirements of ruminants. CAB International, Wallingford, UK. 159pp.
Beef + Lamb NZ 1994. A guide to feed planning for sheep farmers. Beef + Lamb NZ, Wellington. 57pp.

Beef + Lamb NZ 2013. Whole farm analysis New Zealand, class 9 New Zealand all classes. Accessed 1 June 2013. http://www.beeflambnz.com/information/ on-farm-data-and-industry-production/sheep-beeffarm-survey/nz/

Cocks, A.; Williams, M.; Casey, M.; Brown, C.; Ware, J.; Morrison, N.; Morrison, G.; Pearce, G.; Taylor, W.; Cochrane, G.; Cochrane, J.; Harris, T. 2002. Farmers adopting technology to improve sheep production a nine year study. Proceedings of the New Zealand Grassland Association 64: 49-53.

Litherland, A.J.; Woodward, S.J.; Stevens, D.R.; McDougal, D.B.; Boom, C.J.; Knight, T.L.; Lambert, M.G. 2002. Seasonal variations in pasture quality on New Zealand sheep and beef farms. Proceedings of the New Zealand Society of Animal Production 62: 138-142. 